\title{
To the Roots of Identification of Czechs in British Mentality: Comenius and England
}

\author{
Marina Yu. Kotova \\ Faculty of Philology \\ St. Petersburg State University \\ St. Petersburg, Russian Federation \\ e-mail: mariyur@mail.ru
}

\begin{abstract}
British-Czech cultural relations possess a long history of various historical events which have been keeping in a cultural memory of British people as the signs of identification of Czechs in British mentality. Jan Amos Komenský (Comenius) was one of the Czechs whose visit to England had contributed to the construction of this identification.
\end{abstract}

Keywords-Imagology; Identification; cultural memory; Czech identity; British; Comenius; stereotype

\section{INTRODUCTION}

Imagology, an interdisciplinary humanitarian science, leads its 'pre-history' from European scholar Julius Caesar Scaliger (1484 - 1558) and afterwards it was developed by Vico,J.G.Herder, Humboldt, Schlegel and J. Grimm, H. Taine (1863) and others.

It marked itself in the first half of the XX c. with the French, German, American works of its first stage, called 'proto-imagological'. During the XX c. imagology was enriched with such imagological items as Comparative Literature and Comparative Linguistics, national character, cultural stereotype, identity, identification, self-identification, Self-Other opposition, post-colonial theories of F. Fanon (1952) and E. Said (1978) and others.

The contacts between Slavonic and non-Slavonic cultures have been an object of scientific research for many years, mainly from the XIXth c. (the period of natioanl Revival in Slavonic countries Bohemia, Poland, Bulgaria and others). The XX - XXI cc. contributed to the topic of the identification, self-identification and identity of such Slavs as the Czechs with the surveys of Czech and Slovak identity, published by the British, Czech, German and Russian scholars: James D. Naughton (1977), Josef Polišenský (1991), Robert B. Pyncent (1996), A. Nedamová and T. Kostelecký (1996), Olga Rösch (2001), A. Thomas, I. Nový and S. Schroll-Machl (2003), Michael Weigl, Václav Houžvička, Lukáš Novotný and Werner Weidenfeld (2008), Thomas Wünsch (2008), the professors of the Department of Slavonic Philology of Saint-Petersburg State University in Russia $(2010,2014)$ and others [1].
At the end of the XXth c. there appeared in cultural studies a new term, offered by German and French scholars A. Assmann, J. Assmann, P. Nora and others, - Cultural memory [2].

Historical and cultural events, which create the cultural memory of the nation, contribute to the construction of the national and cultural identity, i.e. identification of the 'other' ('odd') culture in the mentality of the 'self' (recipient) culture.

The history and experience of British-Bohemian relations give us many examples of contacts of the Czechs, being on a trip in England, and the British, visiting Bohemia and Moravia. One side of this experience (the Czechs in Great Britain) is brilliantly reflected in a fundamental monography "England with the eyes of Czech literature from Medieval Ages till the year 2000", published by Czech and Moravian scholar Jaroslav Peprník [3].

The data about the importance of visits, long-term stay or immigration of the Czechs in Great Britain could be found out in many other sources, for example in the books of $\mathbf{J}$. Herben, J. Polišenský, R. H. Seton-Watson, T. G. Masaryk, K. Čapek and others.

The remarkable points on the chronological line of the Czechs' visits in Great Britain are connected with the following great persons of the Bohemian history: Queen Anne of Bohemia (1366-1394, in England from 1382, when she, a daughter of the Bohemian king Charles IV, became Queen of England, married to the English King Richard II), the engraver Václav Hollar toiling in London (in England from 1644 till 1677), scholar Jan Amos Comenius (in England in 1641-1642), composer Antonín Dvořák (18411904, in England in 1884), philosopher and politician Thomas Garrigue Masaryk (1850-1937, first visit to England in 1915), writer Karel Čapek (1890-1938, in 1926 visited England) and others.

Let us see in details and make an attempt to analyze the results and significance of the visit to England of outstanding Jan Amos Comenius (Komenský) as a segment of the construction of identification of the Czechs in British mentality and, dare to say, a proto-stereotype of the Czech intellectual. 


\section{COMENIUS AND ENGLAND}

Jan Amos Comenius (1592, Uherský Brod - 1670, Amsterdam) arrived to England on the invitation of English Parliament in September 1641. He remains there till the end of August 1642. He corresponded with English philosophers and scholars prior to his visit as well as afterwards.

His trip to England was his first which he made abroad from his exile in the Polish town of Leszno (he left Bohemia in 1628 and his exile lasted forty-two years).

J. A. Comenius first drew attention to himself with the publication of his work «Janua linguarum reserata» (1631), for which he was recognised in England. This work was translated into English under the title «The Gateway of Languages Unlocked». This book became the main reason for the beginning of correspondence between Jan Amos Comenius and Samuel Hartlib (1600-1662). The latter organized the invitation of Comenius to England in 1641.

A few years before Comenius's arrival to England S. Hartlib published two works of Comenius: "Conatuum Comenianorum praeludia" (1637) and "Comenii pansophiae prodromus et didactica dissertatio" (1639), in which Comenius offered to the British reading public the project of Pansophia, the main philosophical and didactical composition of Comenius, encyclopedia of all the spheres of mankind. S. Hartlib was insistant on his invitation of Comenius to London for working out the principles of Pansophia, for the plan of reforming British system of education and for participation in the foundation of the new English collegium of scholars.

Upon his arrival to England Comenius paid visits to influential people in his capacity as a churchman. Some Englishmen saw in him the one who continued the ideas of F. Bacon and took the ideas of Czech scholar enthusiastically.

However the Irish uprising, Civil war and danger which threatened the supporters and benifactors of Comenius made the continuation of his visit impossible.

Having finished in 1642 in London his opus "Via Lucis" ("The Path of Light"), in which he explained his programme of the pansophy, Jan Amos Comenius left England in the company of John Durye and Peter Figul (Jablonský), who were the members of Hartlib circle.

The remaining sources indicate that after his departure from England Comenius continuously corresponded with S. Hartlib, dicussing with him his didactical and philosophical plans concerning the activity of evangelical Czech Brotherhood headed by Comenius-bishop.

In the archiv of Jan Kvachala (1898) the last letters of Comenius to S. Hartlib are dated March 1658 [4]

In the $20^{\text {th }} \mathrm{c}$. some later letters written by Comenius to the same adressee were found (see the works of Dagmar Čapková, Eva Pasáčková and Jan Kumpera,Vladimír Urbánek, the Czech-Norwegian biographer of Comenius Milada Blekastad, R. F. Young and others) [5].

The evidence remains that he was in contact with other members of Hartlib cicrcle: theologian John Durye, mathematician John Pell, secretary of Royal society Henry Oldenbourgh,a writer John Beale and others.This correspondence according to $\mathbf{J}$. Kvachala remains in archives of the British museum, Oxford University and the Royal society. Nowadays Comenius correspondence is kept in the 36 libraries of 32 European cities the largest of which is archive of the National museum in Prague, Sheffield University and the State Archive in Poznan in Poland.

The friend of Comenius S. Hartlib who was a renowned intellectual of the $17^{\text {th }} \mathrm{c}$. left behind interesting private archives. Correspondence of Comenius with members of Hartlib circle was published in the editions of Comenius, edited by the Czech scholars A. Patera (1897) and J. Kvachala (1898-1902).

In 1947 the English scholar G. H. Turnbull published his work «Hartlib, Dury and Comenius: Gleanings from Hartlib's Papers», which was the beginning of a new research, scholar conferences and projects dedicated to $\mathrm{S}$. Hartlib's work [6].

One of such projects was «Hartlib Papers Project" (1988-2002), carried out in Sheffield University under the leadership of professors M. Greengrass and M. Leslie. On its basis in 2002 the English scholar H. Hotson decided to compile an electronic database, which numbers more than 4000 articles and is available electronically.

John Dury / Durye / Durie (Johannes Dureus, Johannes Duraeus, 1595-1680), who accompanied Comenius on his way to England and on his return was together with S. Hartlib a leading figure in British scholarly society who continuously supported Comenius. Being a Scottish churchman he attempted to unite the Calvinist and the Lutheran wings of the Protestants who made various attempts in uniting though without success. J. Durye was a Pamphlet writer, the influence of the didactic serie of Comenius was revealed in J. Durye's work «The Reformed School» (1648), which was pubished three centuries later in 1958 edited by H. M. Knox.

J. Pell (1611-1685), who was a teacher in Hartlib's school, in his mathematical studies worked under the influence of Pansophialogical ideas outlined by Comenius. J. Pell as well as S. Hartlib and J. Durye left behind his private archive containing correspondence with Comenius and other members of Hartlib's net.

In his books J. Kvachala published the correspondence of Comenius with other persons, among these we can mention Comenius's letters from Amsterdam, addressed to the Royal society or its secretary Henry Oldenbourgh (1615-1677). The letter in 1667 was written by Comenius to H. Oldenbourgh in connection of the translation of the Bible into Turkish and discussion of the possibility of cooperation between English and Dutch scholars of translating the New Testament [7].

A year later on the 1st of April,32 years later after his trip to London and two years before his death 76 -year old Jan Amos Comenius sends to England from Amsterdam his reworked publication "Via Lucis", the original draft to which he finished during his visit to London in 1641-1642. He sends the letter accompanied the publication in which he 
mentions the details of composition of the book and various remarks and corrections. Comenius ends his letter with the request to support the Royal Society in its activities [8].

In the answer to this letter H. Oldenbourgh on the $5^{\text {th }}$ of May writes to Comenius in Amsterdam was thanking him for the present, approving Comenius's efforts concerning the improvement of educational system in England [9].

In J. Kvachala's archive publications two more Amsterdam letters of Comenius are edited. The $1^{\text {st }}$ letter dated $10^{\text {th }}$ of September 1657 addressed to Calam was the request to support two members of Brotherhood - Adam Samuel Hartmann and Pavel Cyril. These two should give this letter to the addressee. In this letter Comenius writes those twenty five years ago, when he was a guest of Calam the latter promised that English will remember the members of Moravian brotherhood and offered to help to them [10].

In the $2^{\text {nd }}$ letter sent from Amsterdam Comenius thanks for the help offers to Hartmann and Cyril and sends his blessing. The addressee of this letter is the London priest $\mathbf{J}$. Stouppius with whom Comenius was not acquainted personally [11].

The missionaries of Moravian Brotherhood, sent by Comenius to England, in later years founded schools near Leeds and at Fairfield, near Manchester, near Derby and organized an active community in London which supported the Protestant revival and the Methodism of John Wesley [12].

According to the material of the Moravian philologist Jaroslav Peprník, published in his book in 2001, Jan Amos Comenius in his opus "Labyrinth of the World and Paradise of the Heart" (1663) highly appreciated the English etiquette traditions, respect and courtesy towards ladies [13].

In England in the end of the $19^{\text {th }} \mathrm{c}$. several monographs were published. One can mention such authors as S. S. Laurie (1898), R. H. Quick (1890) and M. W. Keatinge (1896).In $20^{\text {th }}$ c. the most prominent works of British comenologists were the books of R. F. Young (1932), G. H. Turnbull (1947) and D. Murphy (1995) [14].

The Czech scholar Jan Herben who devoted his book to the study of the Czech reformer John Huss published in England his book"Huss and his Followers" (1926). In this book he mentions Comenius as a follower of J. Huss and evaluates a role of England in the life of Comenius as well as the importance of his visit for British society [15].

\section{CONCLUSION}

On the one hand Jan Amos Comenius's visit to England and his contacts with scholar and religious circles influenced his later activity in reforming education and as the bishop of Moravian Brotherhood and as the creator of the philosophical project Pansophia; his correspondence with the British lasted all his life during his periods of exile to Poland, Sweden, Hungary and Holland. On the other hand, philosophical and didactical works of Jan Amos Comenius influenced, firstly, the evaluation of scholarly thought (ideas) in England, which he wrote prior to 1642 as well as after his departure from England, and secondary, the missionary activities of Czech brothers who were sent by J. A. Comenius to England in the $50-\mathrm{s}$ of the $17^{\text {th }} \mathrm{c}$.
According to Jan Herben, after the defeat in the Battle of the White Mountain near Prague in 1620 and the end of the old Bohemia, "it was only in exile that the Czech nation existed. Whatever was then written in Czech and has any literary value, was produced by the exiles. The literary history of that period knows three names: the exile Pavel Skála, Pavel Stránský and John Amos Komenský“ [16].

In $1926 \mathrm{~J}$. Herben explained in his book the reasons of English tendencies in the creative activities of Jan Amos Comenius: "It was England to which Komenský's political hopes went out /.../ At that time in England, Komenský unfolded in his work "Via Lucis" the idea which kindles our hearts even now. He turned back to the slightly altered idea, first pronounced by our Hussite King, i. e. that a body of the world's savants be formed into a tribunal, to which the nations should appeal in their international disputes, especially those to whom injustice was done" [17].

J. Herben also underlined the difference of attitude to Comenius from the side of the other countries and from his motherland. We read about the foreigners: "His greatness is already expressed in history by the fact that he remained long misunderstood, because his religious, educational and philosophical doctrines were, in that era, 'above the ways of men"' [18] and about the Czechs: "His own nation was the last to appreciate him" [19].

This idea is shown and developed by the follower of $\mathbf{J}$. Herben - Josef Vincent Polišenský, who also was writing in English to widen the knowledge about Bohemia in the world: "Comenius, then a persecuted wandering Bishop of the Unity of Brethren, was writing his "Testament of the dying Mother, the Unity of Brethren" in the bitter knowledge that the Czechs had been sacrificed. He rejected tempting offers from England where, in accordance with his pansophistic ideas, the Royal Society was being founded as well as offers from America to combine activity at Harvard with work among the Indians, because he did not want to be too far away from his own country. Although his educational ideals, like his practical school-apparatus, were not allowed in Bohemia, this great man of the Czech nation, called by Michelet the "Galileo of Education", hoped for a better future for the sorely tried nation. And his compatriots in Poland and Slovakia, who through their work and their lived were building a bridge between the Czech countries and their new homes, shared his belief' [20].

\section{REFERENCES}

[1] Polišenský J. History of Czechoslovakia in Outline. Praha, 1991; Polišenský J. Tisícletá Praha očima cizinců. Praha, 1999; Naughton J. D. The Reception in Nineteenth Century England of Czech Literature and of the Czech Literary Revival. Dissertation submitted for the Degree of Ph.D.at the University of Cambridge. Cambridge, 1977; Pynsent R. Pátrání po identitě, přel. Blanka Hemelíková. Praha, 1996; Nedamová A., Kostelecký T. Národní identita. Praha, 1996; Rösch, Olga (Hrsg) Stereotypisierung des Fremden. Berlin, 2001; SchrollMachl, S., Nový, I. Beruflich in Tschechien. Trainingprogramm für Manager, Fach- und Führungskräfte. Handlungskompetenz im Ausland. Herausgegeben von Alexander Thomas, Universität Regensburg. Vandenhoeck und Ruprecht, Göttingen, 2003; Weigl, M. Tschechen und 
Deutsche als Nachbarn. Spurender Geschichte in grenzregionalen identitäten. Mit Beiträgen von Václav Houžvička und Lukáš Novotný sowie einem Vortwort von Werner Weidenfeld. Baden Baden, 2008; Wünsch, Thomas. Deutsche und Slawen in Mittelalter Beziehungen zu Tschechen, Polen, Südslawen und Russen. München, 2008; Slaviane v neslavianskih stranah / Ed. by M. Yu. Kotova. Vyp. 1. SaintPetersburg., 2010; Segmenty identichnosti v tvorchestve zarubezhnyh slavianskih pisatelej / Ed. by M. Yu. Kotova. Saint-Petersburg., 2014.

[2] Assmann J. Das Kulturelle Gedächtnis: Schrift, Erinnerung und Politische Identität in frühen Hochkulturen. Münich, 1992; Nora P. Realms of Memory: The construction of the French Past. New Jork, 1996; etc.

[3] Peprník J. Anglie očima české literatury od středověku po rok 2000. Olomouc, 2001.

[4] Spisy Jana Amosa Komenského. Číslo 1. Korrespondence Jana Amosa Komenského. Listy Komenského a vrstevníků jeho Nová sbírka. Vydává Dr. Jan Kvačala. Praha, 1898

[5] Čapková, Dagmar, ed., 'Unpublished Letters by Comenius', Acta Comeniana, 2 (1970), pp.285-94; three letters from Comenius to Hartlib and Moriaen, from the Hartlib Papers;

Blekastad, Milada, ed., Unbekannte Briefe des Comenius und seiner Freunde, 1641-1661 (Ratingen, 1976); 33 letters from Comenius to Hartlib, Beale, Figulus, and Arthur Annesley, and nine letters from Johann Moriaen to Comenius and Hartlib, all from the Hartlib Papers; five letters from Figulus to Axel Oxenstierna, from the Riksarkivet in Stockholm; Pasáčková, Eva and Kumpera, Jan, eds., ' $Z$ anglických komenian (Tř́i Komenského dopisy Hartlibovi z let 1657-1662)', Studia Comeniana et historica, 20 (1990), no. 42, pp.41-57; three letters of Comenius to Hartlib, from the Hartlib Papers (one of them already published in Acta Comeniana, 7; here with Latin originals and Czech translations); Urbánek, Vladimír, 'The Network of Comenius' Correspondents', Acta Comeniana, 12 (1997), pp.63-78; Young, R. F., 'Comenius and the Royal Society', The Times
Literary Supplement, 11 Oct 1928, p.736; one letter from Comenius to Oldenburg, in the archives of the Royal Society of London; Young, R. F. Comenius in England. Oxford, 1932.

[6] Turnbull G. H. Hartlib, Dury and Comenius: Gleanings from Hartlib's Papers. Liverpool, 1947.

[7] Spisy Jana Amosa Komenského. Číslo 1. Korrespondence Jana Amosa Komenského. Listy Komenského a vrstevníkủ jeho. Nová sbírka. Vydává Dr. Jan Kvačala. Praha, 1898. S. 326.

[8] Ibidem. P. 342.

[9] Ibidem. P. 351

[10] Ibidem. P. 222

[11] Ibidem. P. 246

[12] Polišenský J. V. History of Czechoslovakia in Outline. Praha, 1991. P. 76.

[13] Peprník J. Anglie očima české literatury od středověku po rok 2000. Olomouc, 2001. P. 139.

[14] Murphy D. Comenius: A Critical Reassessment of his Life and Work. Irish Academic Pr., 1995; Keatinge M. W. The Great Didactic of Comenius. London, 1896; Laurie S. S. John Amos Comenius. London, sixth edition, 1898; Quick R. H. Essays on Educational Reformers. London, 1890.

[15] Herben J. Huss and his Followers. London, 1926. P. 163-191.

[16] ibidem. P. 168.

[17] ibidem. P. 184

[18] ibidem. P. 186

[19] ibidem. P. 187.

[20] Polišenský J. V. History of Czechoslovakia in Outline. Praha,1991. P. 70 